Acta vet. scand. $1970,11,49-58$.

From the Department of Medicine I and the Department of Medicine II, Royal Veterinary College, Stockholm, Sweden.

\title{
RELATIONSHIP BETWEEN SELENIUM CONTENT OF FORAGE, BLOOD AND ORGANS OF SHEEP, AND LAMB MORTALITY RATE*)
}

By

P. Lindberg and S. O. Jacobsson

Several authors have shown the relationship between the selenium content of forage and the incidence of white muscle disease in lambs (Muth et al. 1958, Cousins \& Cairney 1961, Burton et al. 1962, Oldfield et al. 1963, Allaway \& Hodgson 1964, Oksanen 1965, and others) Oldfield et al. were able to produce white muscle disease in the lambs by feeding their dams prenatally a diet containing less than $20 \mathrm{ng}$ of selenium per $\mathrm{g}$ of food. They were also able to prevent the disease by raising the dietary Se level to $60 \mathrm{ng}$ per $\mathrm{g}$.

Se concentration in tissues of the ewes is a reflection of Se concentration in their diet (Burton et al.). Levels of Se in the blood of lambs closely approximate those of their dams; wholeblood levels of $120 \mathrm{ng}$ per $\mathrm{g}$ in the lambs and $110 \mathrm{ng}$ per $\mathrm{g}$ in the ewes are compatible with white muscle disease prevention (Oldfield et al.).

The object of the present work was to investigate the relationship between the Se content of forage and of the organs of the sheep in some Swedish herds and its correlation with the lamb mortality rate.

*) The investigation was supported by grants from Statens Råd för Skogs- och Jordbruksforskning. 


\section{MATERIAL AND METHODS}

Twelve herds in the counties of Stockholm and Uppsala were studied during the winter $1966-1967$ and the spring of 1967 . The number of adult animals in the herds varied from 10 to 112. The sheep were of the Swedish Lantras breed, Texel, or a crossbreed between these two. The herds were chosen among those that were, or had been, recorded for health control of sheep at the Department of Medicine II, Royal Veterinary College, Stockholm. The study comprised herds in which cases of white muscle disease (WMD) had occurred or been suspected in the preceding year and herds in which WMD had not been suspected in the preceding year.

The first visits to the herds were made between December 1966 and February 1967. By then the sheep had been fed indoors for at least 2 months. At the visit samples were taken of the food stuffs used, hay, corn, and concentrates (Table 2).

Table 1. Treatment with selenium and vitamin $E$ in the herds.

Herd no. Treatment

All herds Vitamin $\mathrm{E}$ to the lambs for the first 7 days after birth

1 I.m. injection of IDO-E® to 4 lambs at the age of 4 weeks

5 Tokosel vet. orally*) to the ewes 3 weeks before lambing and i.m. ${ }^{\star *}$ ) to the lambs

8 Tokosel vet. i.m. to 21 of 26 ewes 3 to 6 weeks before lambing and orally on the 6 - 7 th day after lambing

10 Tokosel vet. i.m. to the ewes 6 weeks before lambing. Blood samples were drawn from 3 ewes 1 week after this treatment

11 Tokosel vet. and IDO-E® i.m. ${ }^{* *}$ ) to the lambs at about 2 months of age in connection with an outbreak of white muscle disease. Tokosel vet. orally to the ewes about 3 months after lambing

12 Tokosel vet. to all the lambs once during the first week of life

*) Tokosel powder, $11 \mathrm{~g}$ per $75 \mathrm{~kg}$ body weight, containing $0.4 \mathrm{mg}$ of Se plus $20 \mathrm{mg}$ of tocopheryl acetate per $\mathrm{g}$, mixed in the food. Manufacturers: AB Agrivet, Uppsala, Sweden.

* *) Injection of Tokosel solution, $1 \mathrm{ml}$ per $10 \mathrm{~kg}$ body weight, containing $0.6 \mathrm{mg}$ of Se plus $30 \mathrm{mg}$ of tocopheryl acetate per $\mathrm{ml}$. Manufacturers: AB Agrivet, Uppsala, Sweden.

***) Injection of $3 \mathrm{ml}$ per animal of the IDO-E® solution, containing $100 \mathrm{mg}$ of tocopheryl acetate per ml. Manufacturers: Ferrosan, Malmö, Sweden. 
Blood specimens with added heparin were taken from 2-11 sheep in each herd. If a herd included groups of sheep fed different diets, blood samples were drawn from at least 2 sheep in each group. If possible samples from kidney, liver, and muscle were drawn from animals that were slaughtered or died over the period December-May.

The forage samples were ground and the Se content in these as well as in the samples of blood and organs was measured by a fluorometric method (Lindberg 1968).

In order that the owners should not suffer any losses on account of the investigation, the lambs or ewes were treated with vitamins and selenium, as shown in Table 1 . With the exception of those in herd no. 10, the ewes were not treated prior to blood sampling. Dead lambs were as far as possible collected for necropsy, unless they had evidently died from some other cause, for instance obstructed labour, or had been killed because of malformation. In the autumn of 1967 data were collected from the owners concerning the number of births and deaths of lambs (Table 4).

In connection with a mass outbreak of illness with symptoms of WMD in herd no. 11, blood samples were drawn from 11 lambs, chosen arbitrarily, and examined for GOT (glutamicoxaloacetic transaminase) levels by Reitman \& Frankel's (1957) method.

The relation between the Se content of forage and that of whole blood of the ewes was tested by correlation analysis.

\section{RESULTS}

The Se content of the forage fed to the herds is shown in Table 2. The mean content for all the herds was as follows: Hay $21 \mathrm{ng}$, corn $17 \mathrm{ng}$, concentrate mixture $159 \mathrm{ng}$, pellets (concentrates) $159 \mathrm{ng}$, and beets $171 \mathrm{ng}$ per $\mathrm{g}$. The lowest value, $8 \mathrm{ng}$ of Se per g, was obtained for hay from herd no. 12 and the highest value, $310 \mathrm{ng}$ of Se per $\mathrm{g}$, for beet pulp from herd no. 9 .

The Se content of the forage consumed per animal and day was calculated on the basis of the Se analyses of the feed stuffs and the rations fed at the time of sampling, as stated by the owners. These values and those for blood and organs are shown in Table 3 and Fig. 1. There was a significant $\left(r=0.79^{\star \star \star}\right)$ correlation between the Se content of the forage and that of the whole blood of the ewes. The highest value, $62 \mathrm{ng}$ per $\mathrm{g}$ of forage, 


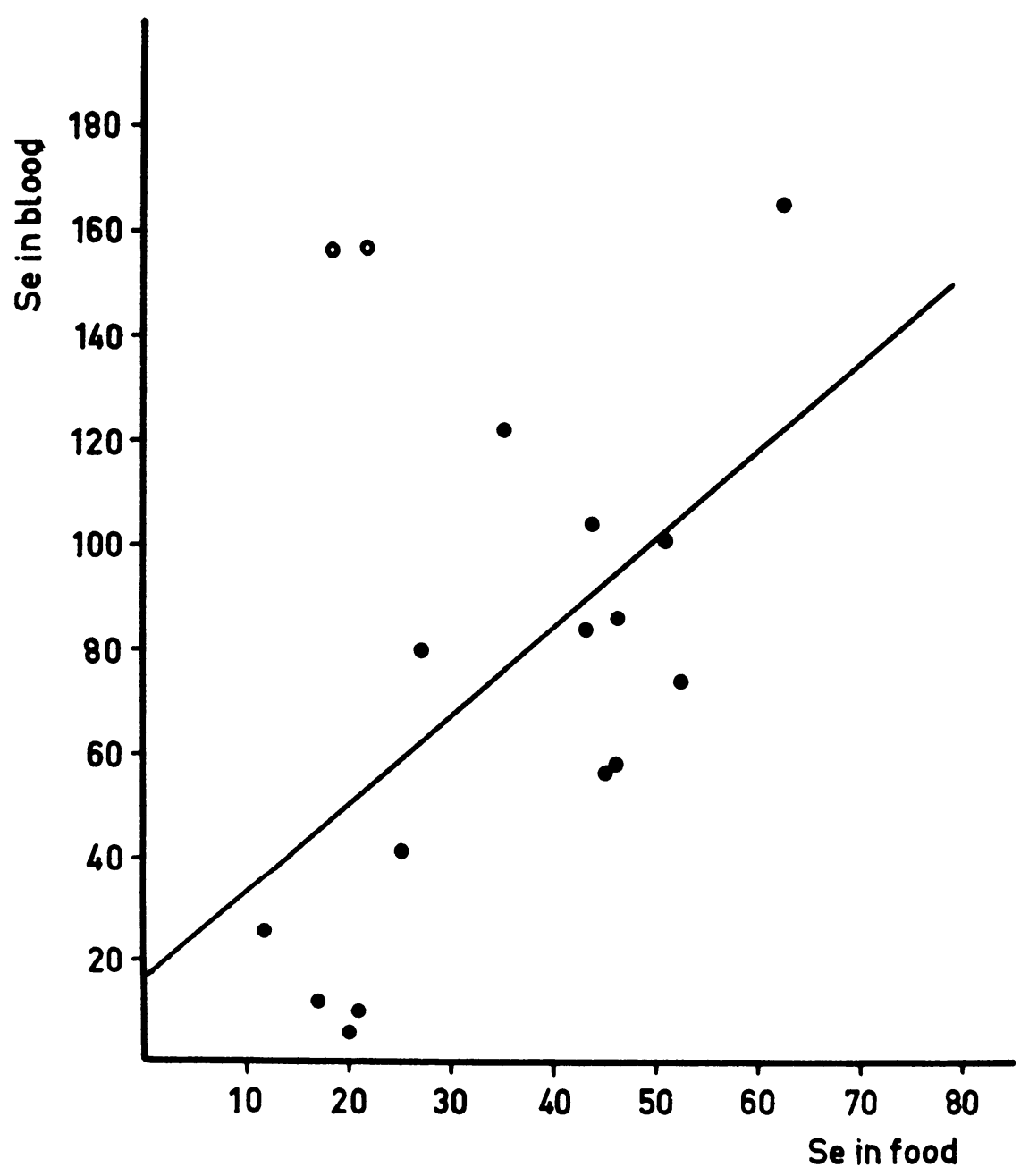

Fig u r e 1. Selenium content in blood of sheep $(\mathrm{ng} / \mathrm{ml})$ in relation to selenium content in food ( $\mathrm{ng} / \mathrm{g}$ of dry substance).

o treated with Se.

- untreated. 
T a b l e 2. Selenium content of forage expressed as ng of Se per $\mathrm{g}$ dry weight.

\begin{tabular}{rrcccc}
\hline Herd no. & Hay & Corn & $\begin{array}{c}\text { Concentrate } \\
\text { mixture }\end{array}$ & Pellets & $\begin{array}{c}\text { Beet } \\
\text { pulp }\end{array}$ \\
\hline 1 & 21 & - & - & 198 & - \\
2 & 25 & - & 102 & - & - \\
3 & 18 & - & - & 145 & - \\
4 & 27 & 33 & - & - & - \\
5 & 24 & 18 & - & 158 & - \\
6 & 22 & - & 188 & - & 165 \\
7 & 33 & - & 188 & - & 165 \\
8 & 11 & 10 & - & - & - \\
9 & 23 & 15 & - & - & 310 \\
10 & 14 & - & - & - & - \\
11 & 21 & 10 & - & - & - \\
12 & 8 & - & - & 155 & 171 \\
\hline Mean & 21 & 17 & 159 & & \\
\hline
\end{tabular}

was obtained in herd no. 3, group b. The concentrations in organs and blood of the animals in this herd were also high; $165 \mathrm{ng}$ of Se per ml whole blood was the highest value met. The lowest value was $11 \mathrm{ng}$ per $\mathrm{g}$ of forage in herd no. $8 \mathrm{a}$. The content was slightly higher, but still low, in herds nos. 12 and 11, being $17 \mathrm{ng}$ and $20 \mathrm{ng}$ per g, respectively. The Se content in whole blood and organs of the animals in these herds was also the lowest, 5-12 ng per ml of whole blood.

Table 4 shows the lamb mortality in the herds. It was lowest in herds nos. 3 and 5 . It was also low in nos. 10, 2, 6, and 1. The highest mortality rates, $25 \%, 16 \%$, and $9 \%$, were found in herds nos. 12, 11, and 8 , respectively. White muscle disease was the cause of death in 1 out of 2 and 3 out of 7 necropsy cases in lambs from herds 8 and 11, respectively. These lambs died between the ages of 1 and 67 days. Elevated GOT levels ( $>740$ units) were noted in 9 out of 11 blood samples from lambs in herd no. 11.

\section{DISCUSSION}

The investigation showed that the selenium content of hay and corn was lower than $60 \mathrm{ng}$ per $\mathrm{g}$. This is the minimum content required for prevention of WMD in sheep (Oldfield et al. 1963, Mikkelsen \& Hansen 1968). Gardiner et al. (1962) set the lower limit at $30 \mathrm{ng}$ and Allaway \& Hodgson (1964) at $100 \mathrm{ng}$ 
T a ble 3. Selenium content of organs ${ }^{\star}$ ) and forage, ng Se per g dry weight.

\begin{tabular}{|c|c|c|c|c|c|c|c|c|}
\hline \multirow{2}{*}{$\begin{array}{l}\text { Herd/farm } \\
\text { no. }\end{array}$} & \multicolumn{2}{|c|}{ Blood*") } & \multirow[t]{2}{*}{$\mathbf{n}$} & \multirow{2}{*}{$\underset{x}{\operatorname{Liver}}$} & \multirow{2}{*}{$\underset{x}{\text { Kidney }}$} & \multirow{2}{*}{$\underset{x}{\operatorname{Muscle}}$} & \multirow{2}{*}{$\underset{x}{\text { Forage }}$} & \multirow{2}{*}{ Comments } \\
\hline & $\bar{n}$ & $\mathbf{x}$ & & & & & & \\
\hline 1 & 2 & 103 & - & - & - & - & 44 & \\
\hline $2 \mathbf{a}$ & 2 & 122 & 1 & 230 & - & 165 & 35 & Rams given hay only \\
\hline $2 \mathrm{~b}$ & 3 & 41 & 1 & 100 & - & 56 & 25 & \\
\hline 3 a & 2 & 59 & - & - & - & - & 46 & \\
\hline $3 \mathrm{~b}$ & 5 & 165 & 5 & 647 & 6880 & 224 & 62 & $\begin{array}{l}\text { Lambs on a fattening diet } \\
\text { including pellets }\end{array}$ \\
\hline $3 \mathrm{c}$ & 4 & 157 & 4 & 456 & 6460 & 173 & 18 & $\begin{array}{l}\text { Ewes given pellets } 11 / 2 \\
\text { months before sampling }\end{array}$ \\
\hline 4 & 2 & 80 & - & - & - & 一 & 27 & \\
\hline 5 & 2 & 84 & - & - & - & - & 43 & \\
\hline 6 & 3 & 74 & - & - & - & - & 52 & \\
\hline 7 & 4 & 87 & 3 & 667 & 7760 & 153 & 46 & \\
\hline 8 a & 2 & 26 & - & - & - & - & 11 & \\
\hline $8 \mathrm{~b}$ & - & - & 2 & 405 & 2360 & 98 & - & $\begin{array}{l}\text { Organs from suckling } \\
\text { lambs }\end{array}$ \\
\hline 9 & 2 & 57 & - & - & - & - & 45 & \\
\hline 10 & 3 & 157 & - & - & - & - & 22 & $\begin{array}{l}\text { Tokosel i.m., } 1 \text { week be- } \\
\text { fore sampling }\end{array}$ \\
\hline $11 \mathrm{a}$ & 2 & 10 & - & - & - & - & 21 & \\
\hline $11 \mathrm{~b}$ & 2 & 5 & 2 & .54 & 1300 & 19 & 20 & Rams \\
\hline $11 \mathrm{c}$ & - & - & 1 & 76 & - & 37 & - & $\begin{array}{l}\text { Suckling lambs; white } \\
\text { muscle disease }\end{array}$ \\
\hline 12 & 2 & 12 & - & - & - & - & 17 & \\
\hline
\end{tabular}

*) Unless otherwise stated under Comments, specimens from blood and organs were taken from pregnant ewes.

* *) ng Se per ml of whole blood.

per g. In the present study the Se concentration in beet pulp, pellets, and mixed forage containing oil concentrates exceeded $60 \mathrm{ng}$ per g. The analyses of hay, corn, and concentrates showed largely the same Se levels as those reported by Oksanen (1965) from Finland and Mikkelsen \& Hansen from Norway.

The results show that the Se content of whole blood was highly positively correlated with that of the forage. Analyses of whole blood from some pregnant ewes in a herd would therefore be a useful means of checking that the Se content of the diet fed to the animals is adequate. It is much easier to analyse the blood than the forage. With the guidance of the analytical results it can then be decided whether prophylactic selenium treatment or correction of feeding would be necessary. The addition of beet 
T a b le 4. Lamb mortality and incidence of white muscle disease in the investigated herds.

\begin{tabular}{|c|c|c|c|c|c|}
\hline \multirow{2}{*}{$\begin{array}{l}\text { Herd } \\
\text { no. }\end{array}$} & \multicolumn{3}{|c|}{ Number of lambs } & \multirow[t]{2}{*}{ WMD } & \multirow{2}{*}{ Comments } \\
\hline & born & stillborn & dead & & \\
\hline 1 & 41 & 1 & 1 & $(+)$ & $\begin{array}{l}1 \text { lamb with fracture of lum- } \\
\text { bar vertebra, } 2 \text { sick lambs } \\
\text { improved on vitamin } E\end{array}$ \\
\hline 2 & 200 & 2 & 4 & - & $\begin{array}{l}3 \text { malformed, } 1 \text { of those born } \\
\text { alive was gored to death }\end{array}$ \\
\hline 3 & 44 & $\mathbf{0}$ & $\mathbf{0}$ & - & Dystocia in 2 ewes with twins \\
\hline 4 & 37 & 4 & $\mathbf{0}$ & 一 & \\
\hline 5 & 19 & $\mathbf{0}$ & $\mathbf{0}$ & 一 & \\
\hline 6 & 137 & 5 & $\mathbf{0}$ & - & \\
\hline 7 & 94 & 2 & 2 & - & $\begin{array}{l}2 \text { ewes gave birth to triplets: } \\
1 \text { lamb from each ewe died }\end{array}$ \\
\hline 8 & 43 & 2 & 2 & + & $\begin{array}{l}1 \text { lamb died in convulsions in } \\
\text { 3rd week of life; necropsy: } \\
\text { no abnormalities }\end{array}$ \\
\hline 9 & 144 & 0 & 11 & - & $\begin{array}{l}\text { Died within } 2-3 \text { days after } \\
\text { birth, because the ewes } \\
\text { abandoned their lambs }\end{array}$ \\
\hline 10 & 39 & $\mathbf{0}$ & 1 & & $\begin{array}{l}\text { The lamb died of intestinal } \\
\text { infection }\end{array}$ \\
\hline 11 & 80 & 5 & 8 & +++ & \\
\hline 12 & 88 & 6 & 16 & - & \\
\hline
\end{tabular}

- = no animals submitted to necropsy or clinical examination.

$(+)=$ clinically suspected cases of WMD.

$+=a$ few cases of WDM demonstrated at necropsy.

$+++=$ several cases of WMD demonstrated at necropsy; elevation of GOT levels in most of the lambs.

pulp or high-protein feed stuffs proved to be of great importance in satisfying the selenium requirement of the sheep. This is illustrated, for instance, by the difference between groups a and $b$ in herd no. 2. The animals in group a, which, in addition to hay, received corn mixed with oil concentrates and beets, had a higher Se content in blood and organs than had the animals in group $b$, which were fed hay alone. The corn probably did not increase the amount of selenium received by group a, as corn and hay of Swedish origin are largely on the same level. This is evident from the forage analyses in the present study and from previous investigations by Lindberg (1968).

The results of the selenium analyses of whole blood indicate that many of the animals had too low selenium concentrations. 
In 9 out of the 12 herds the Se content was below the level established by Oldfield et al. of $110 \mathrm{ng}$ per g, which provides protection against WMD. The Se content in liver specimens from 1 (no. 11) of the 5 investigated herds was lower than the critical borderline values published by Cousins \& Cairney (1961) and Allaway et al. (1966) namely $180 \mathrm{ng}$ and $210 \mathrm{ng}$ per g, respectively. The Se content of muscle and kidney from sheep in the same herd was also on a level which these authors regard as representative of animals with WMD.

A clear relationship was noted between lamb mortality rate and Se content of whole blood and organs from the animals. The mortality rate was low in herds $3,10,2$, and 1 , in which the selenium values were high. On the other hand, it was high in herds like nos. 12 and 11, in which the Se content of blood and organs was low. The necropsies and clinico-chemical analyses showed that the incidence of WMD was high in herd no. 11. This agrees with the observations of other authors (Cousins $\&$ Cairney, Oldfield et al., Allaway et al.) at equally low selenium concentrations in blood and organs. No dead lambs from herd no. 12 were sent to us for necropsy. According to the owner's information, the lambs were dead at birth or were in poor general condition at birth and died within 1 or a few days. There is much evidence indicating that death was due to congenital white muscle disease.

The lamb mortality rate was also influenced by factors other than selenium deficiency, for instance dystocia, intestinal infections, and traumatic injuries (herds nos. 1 and 2). Some of the ewes in herds nos. 7 and 9 abandoned their lambs, which died from lack of nourishment. Two lambs, each from a set of triplets, and some other lambs were lost in this way. In some cases the cause of death is not known, either because the lambs were not submitted for necropsy or because necropsy failed to establish the cause of death.

The lamb mortality rate in the herds fed a low-selenium diet was obviously reduced by treatment with selenium plus vitamin E. The selenium treatment of the ewes in herd no. 10 is probably the reason why the Se level of the blood from these animals deviates so markedly with respect to the correlation between the Se content of forage and that of the blood. The ewes in herds nos. 5 and 8 were treated prophylactically with selenium plus vitamin $E, \therefore \approx$ vill be seen from Table 1. No lambs from the treated ewes 
in these 3 herds died of WMD. But necropsy showed WMD in 1 lamb from an untreated ewe in herd no. 8. The time for the treatment seems to be of importance for its result. The prophylactic selenium and vitamin-E treatment of the lambs in herd no. 12, given once during the first week of life, had no noticeable effect and cannot be recommended as the sole measure in herds fed diets with very low selenium contents.

\section{REFERENCES}

Allaway, W.H.\& J.F. Hodgson: Symposium on nutrition, forage and pastures: Selenium in forages as related to the geographic distribution of muscular dystrophy in livestock. J. Animal Sci. 1964, 23, 271-277.

Allaway, W. H., D. P. Moore, J. E. Oldfield \& O. H. Muth: Movement of physiological levels of selenium from soils through plants to animals. J. Nutr. 1966, 88, 411-418.

Burton, V., R. F. Keeler, K. F. Swingle \& S. Young: Nutritional muscular dystrophy in lambs - Selenium analysis of maternal, fetal, and juvenile tissues. Amer. J. vet. Res. 1962, 23, 962-965.

Cousins, F. B. \& I. M. Cairney: Some aspects of selenium metabolism in sheep. Aust. J. agric. Res. 1961, 12, 927-943.

Gardiner, M. R., J. Armstrong, H. Fels \& R. N. Glencross: A preliminary report on selenium and animal health in western Australia. Aust. J. exp. Agric. Animal Husb. 1962, 2, 261-269.

Lindberg, P.: Selenium determination in plant and animal material and in water. A methodological study. Acta vet. scand. 1968, Suppl. 23.

Mikkelsen, T. \& M. Aas Hansen: Nutritional muscular degeneration (NMD) in lambs. Nord. Vet.-Med. 1968, 20, 402-419.

Muth, O. H., J. E. Oldfield, L. F. Remmert \& J. A. Schubert: Effects of selenium and vitamin $\mathrm{E}$ on white muscle disease. Science 1958, 128, 1090.

Oksanen, H. E.: Studies on nutritional muscular degeneration (NMD) in ruminants. Acta vet. scand. 1965, 6, Suppl. 2.

Oldfield, J. E., J. R. Schubert \& O. H. Muth: Implications of selenium in large animal nutrition. J. agric. Fd Chem. 1963, 11, 388-390.

Reitman, S. \& S. Frankel: A colorimetric method for the determination of serum glutamic oxalacetic and glutamic puruvic transaminases. Amer. J. clin. Path. 1957, 28, 56-63.

\section{SUMMARY}

The investigation comprised 12 herds, totalling 660 sheep, in the counties of Stockholm and Uppsala. The selenium content of specimens of forage, whole blood, muscle, liver, and kidney was determined by a fluorimetric method. Data on the number of born and dead lambs were collected $4-5$ months after lambing. Dead and sick lambs 
were subjected to necropsy and to clinico-chemical analyses, respectively.

The selenium content of hay and corn was lower than $60 \mathrm{ng}$ per g, which some authors regard as the minimum level of Se requirement for protection against white muscle disease in sheep. The analyses of forage mixtures containing oil concentrates and beet pulp showed selenium levels that were about $2-5$ times as high as this minimum level.

In herds in which the animals had not been treated with selenium preparations prior to sampling, there was a significant positive correlation between the selenium content of the forage and that of whole blood. A relationship was also noted between the selenium content of forage and of organs.

In 9 out of the 12 herds the selenium concentrations in whole blood were on the level that is considered to be representative of white muscle disease.

A high mortality rate was recorded for lambs whose mothers had low selenium levels in their blood.

Prophylactic and curative treatment with selenium plus vitamin $E$ orally and/or parenterally probably reduced lamb mortality rate in the herds fed a low-selenium diet.

\section{SAMMANFATTNING \\ Selenhalten $i$ fodret korrelerad till selenhalten $i$ fårens blod och organ och till lammdödligheten.}

Undersökningen utfördes på material från 12 besättningar inom Stockholms och Uppsala län med totalt 660 får. Selenhalten i foder, helblod, muskulatur, lever och njurar undersöktes med en fluorometrisk metod. Uppgifter om antalet födda och döda lamm insamlades 4-5 månader efter lamningen. Obduktioner och klinisk-kemiska undersökningar utfördes på döda respektive sjuka lamm.

Selenhalten i hö och spannmål var lägre än $60 \mathrm{ng} \mathrm{Se/g,} \mathrm{vilket} \mathrm{en}$ del tidigare författare anser vara ett minimivärde för att muskeldegeneration ej skall uppträda hos får. I kraftfoderblandningar med oljekraftfoder och i betfor erhölls analysvärden som var omkring $2-5$ gånger detta gränsvärde.

I besättningar, där behandling med selenpreparat ej vidtagits före provtagningen, förelåg en signifikant positiv korrelation mellan selenhalten $\mathrm{i}$ fodret och $\mathrm{i}$ helblodet. Ett samband kunde även ses mellan koncentrationen $\mathrm{i}$ foder och organ.

Selenvärdena $\mathrm{i}$ helblodet låg i 9 av de 12 besättningarna på sådan nivå som anses representativ för muskeldegeneration.

En hög dödlighet noterades hos lamm, vars mödrar hade låg selenkoncentration i blodet.

Profylaktisk och terapeutisk behandling med selen + E-vitamin oralt och/eller parenteralt sänkte sannolikt lammdödligheten $i$ besättningar med selenbrist i utfodringen. 